\title{
Variability of the pancreatic islet beta cell/iver (GLUT 2) glucose transporter gene in NIDDM patients
}

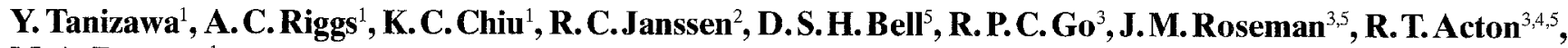 \\ M. A.Permutt ${ }^{1}$ \\ ${ }^{1}$ Division of Endocrinology, Diabetes, and Metabolism, Department of Internal Medicine, Washington University School \\ of Medicine, St. Louis, Missouri, USA \\ 2 Arizona State University, Department of Zoology, Tempe, Arizona, USA \\ ${ }^{3}$ Department of Epidemiology, School of Public Health, University of Alabama, Birmingham, Alabama, USA \\ ${ }^{4}$ Department of Microbiology, School of Medicine, University of Alabama, Birmingham, Alabama, USA \\ ${ }^{5}$ Department of Medicine, School of Medicine, University of Alabama, Birmingham, Alabama, USA
}

\begin{abstract}
Summary The purpose of these experiments was to test the hypothesis that impaired glucose-stimulated insulin secretion in NIDDM is due to mutations in the islet beta cell/liver glucose transporter (GLUT 2) gene. Using oligonucleotide primers flanking each of the 11 exons, the structural portion of the gene was studied by PCR-SSCP analysis. DNA from African-American females $(n=48)$, who had gestational diabetes but developed overt NIDDM after delivery, was studied. Each SSCP variant was sequenced directly from genomic DNA. Two amino acid substitutions from the previously reported sequence were found, one in exon 3 and the other in exon 4B. Four additional silent mutations in the coding region, and six intron mutations outside the splice junction consensus sequences, were also identified. The mutation GTC $\times$ ATC in exon $4 \mathrm{~B}$ substituted $\mathrm{Val}^{197}$ to $\mathrm{Ile}^{197}$. This amino acid substitution was found in only one NIDDM patient in a single allele, and was not found in 52 control subjects. This residue exists in the fifth membrane spanning domain, and $\mathrm{Val}$ at this position is conserved in mouse and rat GLUT 2, and human GLUT 1 to GLUT 4. The other
\end{abstract}

codon change in exon $3, \mathrm{ACT} \times \mathrm{ATT}$, substituted $\mathrm{Thr}^{110}$ to $\mathrm{Ile}^{110}$ in the second membrane spanning domain. To determine the frequency of this non-conservative amino acid substitution, a PCR-LCR assay was developed. This assay was simple and highly specific for detection of this single nucleotide substitution. The allelic frequency of the ATT (Ile ${ }^{110}$ ) in NIDDM patients $(39.6 \%, n=48)$ and that in controls $(47.1 \%$, $n=52$ ) did not differ ( $p=0.32$, Fisher's exact test). In conclusion, we identified two variant GLUT 2 glucose transporters in a subset of NIDDM patients. The rare variant in exon $4 \mathrm{~B}$ may contribute to the diabetic susceptibility and awaits further investigation. However, structural abnormalities of the GLUT 2 transporter associated with NIDDM appeared to be rare and were not likely to be a major determinant of genetic susceptibility to this type of diabetes in the population studied. [Diabetologia (1994) 37:420-427]

Key words: NIDDM, glucose transporter, allele, genotype.
Non-insulin-dependent diabetes mellitus (NIDDM) is a heterogeneous disorder characterized by inappropri-

Received: 19 July 1993

and in revised form: 11 November 1993

Corresponding author: Dr. M. A. Permutt, Metabolism Division, Washington University School of Medicine, 660 South Euclid, Box 8127, St. Louis, MO 63110, USA

Abbreviations: NIDDM, Non-insulin-dependent diabetes mellitus; GLUT 2, islet beta cell/liver glucose transporter; PCR, polymerase chain reaction; SSCP, single strand conformation polymorphism; LCR, ligase chain reaction; bp, base pair ate insulin secretion from pancreatic islet beta cells, and impaired insulin action on target tissues [1]. Genetic as well as environmental factors appear to determine susceptibility to this disorder [2-4]. Recent advances in molecular biology/genetics have provided the opportunity to study several candidate genes in this disorder and mutations associated with NIDDM were identified in a small number of patients in insulin and insulin receptor genes [5-7] and mitochondrial genes [8-10]. Mutations in glucokinase have been implicated in contributing to early-onset autosomal dominant type of NIDDM [11-13], however this type of diabetes also appeared to be rare $(<2 \%)$ [14]. Therefore 
Table 1. Clinical features of study subjects

\begin{tabular}{lll}
\hline & $\begin{array}{l}\text { NIDDM } \\
\text { patients }\end{array}$ & $\begin{array}{l}\text { Control } \\
\text { subjects }\end{array}$ \\
\hline$n$ & 48 & 52 \\
Age at entry (years) & $28.3 \pm 5.4$ & $21.1 \pm 5.0^{\mathrm{a}}$ \\
Age at last follow-up (years) & $34.5 \pm 6.9$ & - \\
Body mass index (kg/m $\left.{ }^{2}\right)$ & $36.4 \pm 8.7$ & $23.7 \pm 4.8^{\mathrm{a}}$ \\
Age at diagnosis of overt dia- & $31.7 \pm 6.0$ & - \\
betes (years) & & \\
Family history of diabetes & $89 \%$ & $14 \%$ \\
Treatment during pregnancy & & \\
$\quad$ Diet & $36 \%$ & \\
$\quad$ Insulin & $64 \%$ & \\
Treatment at last follow-up & & \\
$\quad$ Diet alone & $8 \%$ & \\
$\quad$ Insulin & Oral agents \\
$\quad$ None & $39 \%$ & \\
\hline
\end{tabular}

Values are shown as mean $\pm \mathrm{SD}$ or percent. ${ }^{\mathrm{a}} p<0.001$

genetic factors determining susceptibility to NIDDM are still largely unknown.

GLUT 2, the major glucose transporter isoform of pancreatic islet beta cells, is also expressed in hepatocytes and in epithelial cells of the kidney and small intestine $[15,16]$. This glucose transporter is unique because of its low affinity for glucose $\left(K_{\mathrm{m}} 15-20 \mathrm{mmol} / 1\right)$, in contrast to other high affinity glucose transporters which are saturated at $1-3 \mathrm{mmol} / 1$ glucose [17]. GLUT 2 and glucokinase, a low affinity hexokinase with a $\mathbf{K}_{\mathrm{m}}$ for glucose within the physiological range of plasma glucose, are co-localized in islet beta cells. This observation led to the hypothesis that these two proteins operate in tandem to provide islet beta cells with a mechanism responding to subtle changes in plasma glucose concentrations $[18,19]$. Although the first phosphorylation step of glucose catalysed by glucokinase is the rate limiting step [20], glucose must be transported rapidly into the cell. High transport capacity of GLUT 2 maintains the rapid equilibrium of glucose concentration across the plasma membrane in the wide range of changes of plasma glucose [21.]. Thus GLUT 2 plays a permissive role in the earliest stage of the glucose sensing mechanism. Furthermore, the possibility of physical interaction between GLUT 2 and glucokinase to form a junctional glucose sensing system has been suggested $[18,19]$. Therefore, significant reduction of transporter function caused by inherited defects in the gene may lead to a characteristic of NIDDM, i.e. inappropriate insulin secretion relative to the plasma glucose concentration. Thus, the gene encoding this transporter has been considered as a prime candidate for the determinants of genetic susceptibility to NIDDM.

Previous analyses of the GLUT 2 locus by population studies [22-24] and by linkage analyses in the pedi- grees of familial autosomal dominant early-onset NIDDM [11, 25] and late-onset NIDDM [13, 24, 26] failed to show evidence of the contribution of this locus to the genetic susceptibility to NIDDM, with the exception of one positive association study [27]. Population studies are limited in sensitivity to detect heterogeneity within the disease locus [28]. The multifactorial nature of NIDDM also hampers linkage analysis in families $[29,30]$. Thus, the contribution of GLUT 2 mutations to the genetic susceptibility to NIDDM has not been determined.

To circumvent the limitations of population and linkage studies, we have employed direct single nucleotide level analysis of the gene by PCR-SSCP analysis [31] and studied 48 African-American females with NIDDM. We also developed a simple highly specific method for detection of single base changes using thermostable DNA ligase and PCR. This method was applied to determine the frequency of a common amino acid substitution in exon 3 of the GLUT 2 gene, detected by SSCP and sequencing.

\section{Subjects and methods}

\section{Subjects}

Study subjects were chosen from African-American females who were ascertained through diagnosis of gestational diabetes during pregnancy, and development of overt diabetes after delivery. We chose this subtype of NIDDM because beta-cell defects were likely to be involved in the development of the disease (see Discussion). This is a subsample from a previous study [32, 33]. The first 48 overt diabetic patients were included for the present study and were studied by PCR-SSCP analysis for each exon. The clinical characteristics are shown in Table 1. Although the control groups were younger and leaner than study group, they were matched for the ethnic group, and they received similar prenatal care and gave birth within the same health care system [33]. The difference in the family history ( $89 \%$ vs $14 \%$ ) merely reflected the hereditary nature of NIDDM. Interestingly, only $32 \%$ of study subjects had a family history of NIDDM in the first degree relatives. The study was conducted under the approval of the Human Studies Committee and informed consent was obtained from all participants.

\section{PCR-SSCP analysis}

GenomicDNA was extracted from peripheral blood nuclearcells [34] and exons of the GLUT 2 gene, including exon-intron boundaries, were amplified using flanking oligonucleotide primers shown in Table 1 (Primersequences were generously provided by Dr. G. I. Bell, University of Chicago, Chicago, Ill., USA). Oligonucleotides were synthesized on an ABIDNA synthesizer Model $380 \mathrm{~B}$ by the Protein Chemistry Laboratory at Washington University Medical Center. PCR reactions were performed in $10 \mu$ volumes for 30 cycles as described [35]. Annealing temperatures and $\mathrm{MgCl}_{2}$ concentrations used for each amplification reaction are shown in Table 2. For exons 3 and $4 \mathrm{~A}$, primers (both forward and reverse primers for exon 3 and forward primer for exon 4A) were $5^{\prime}$ end-labelled with $\left[\gamma^{32}\right.$ P]ATP (NEN Products, Bos- 


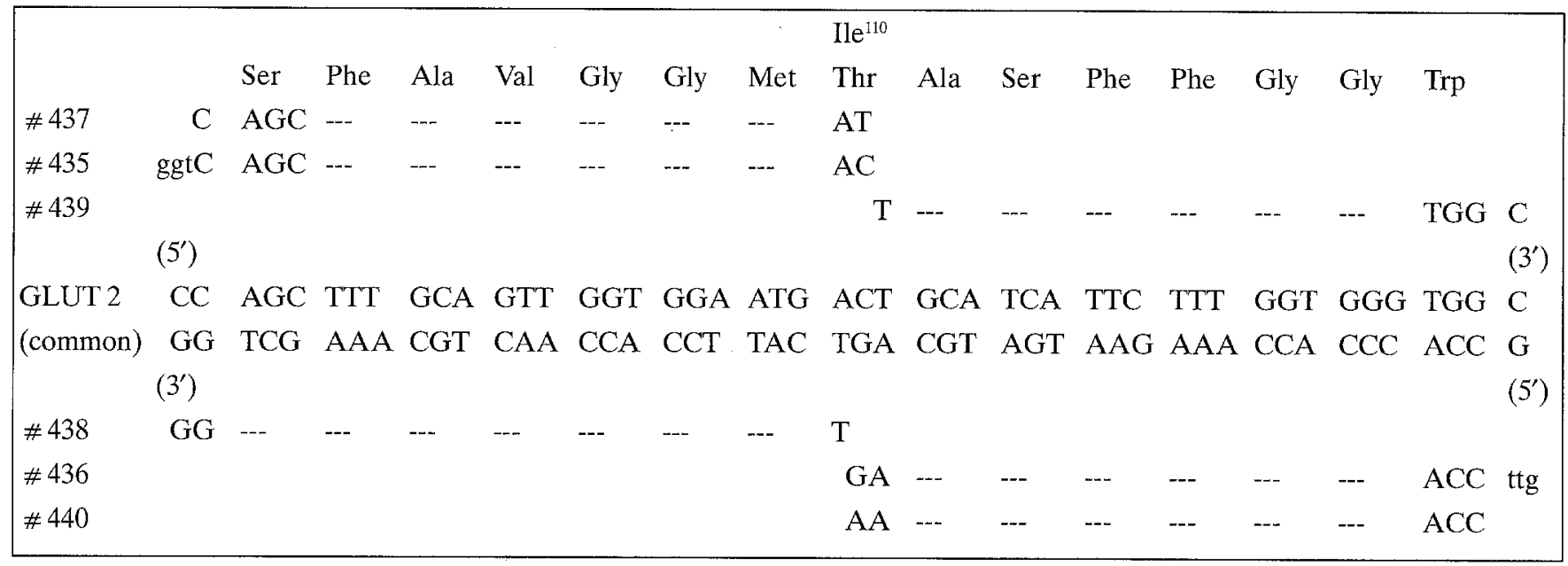

Fig. 1. Oligonucleotides used for LCR. The partial nucleotide sequence of exon 3 (middle) and amino acid sequence of corresponding region (top) are also shown. The polymorphic nucleotides are underlined. Three non-complementary nucleotides were added on the ends of Thr-specific oligonucleotides (\# 435, \#436, shown by lower cases) so that ligation products for each allele could be distinguished by polyacrylamide gel electrophoresis

ton, Mass., USA). All other exons were uniformly labelled with $\left[\alpha-{ }^{32} \mathrm{P}\right] \mathrm{dCTP}$ (NEN) during PCR. Exon 3 and exons 9-10 PCR products were cut with PvuII or RsaI, respectively, prior to SSCP electrophoresis to increase the sensitivity of the analysis. Exon 4 APCR product was cut with BsmA1 to remove the polymorphic CA repeat region that is located in the intron 9 bp downstream from exon $4 \mathrm{~A}$ [36]. Restriction digestion was performed under the following conditions: $10 \mu 1$ PCR product, $1 \times$ recommended restriction buffer, $1 \mathrm{mg} / \mathrm{ml}$ bovine serum albumin, 4-6 U restriction enzyme in a total volume of $15 \mu \mathrm{l}$. Digests were incubated at the appropriate temperature for $3 \mathrm{~h}$.

Six microlitres of stop solution containing $95 \%$ formamide, $20 \mathrm{mmol} / \mathrm{L}$ EDTA were added to the PCR reaction following thermal cycling. After heat-denatured by boiling for $5 \mathrm{~min}, 4 \mu \mathrm{l}$ of the mixture was then analysed by two types of gels; $5 \% \mathrm{Hy}$ drolink (AT Biochem, Malvern, Pa., USA), $1 \times$ TBE gel $(0.089 \mathrm{mmol} / 1$ Trizma base, $0.089 \mathrm{mmol} / 1$ Boric acid, $0.002 \mathrm{mmol} / 1$ EDTA) electrophoresed at $4-6 \mathrm{~W}$ for $16 \mathrm{~h}$, and $8 \%$ polyacrylamide (100: 1 acrylamide:bis-acrylamide), $5 \%$ glycerol, $1 \times$ TBE gel run at $11-14 \mathrm{~W}$ for $16 \mathrm{~h}$. Both were run with $1 \times$ TBE electrophoresis buffer. Gels were then dried and exposed to autoradiograph film with intensifying screen for 3 to $5 \mathrm{~h}$ at $-80^{\circ} \mathrm{C}$.

Sequencing of PCR products, in which variations were observed on SSCP, was performed using the cycle sequencing kit (Bethesda Research Laboratories, Gaithersburg, Md., USA) as previously described [35]. The sequence was confirmed by sequencing in both directions. For GTC $\times$ ATC change in exon 4B substituting $\mathrm{Val}^{197}$ to Ile, and the intron 5 common polymorphism, the presence of the base substitution was further confirmed by the restriction digestion of the PCR products. The exon $4 \mathrm{~B}$ variant removes a Mae III restriction site, and the intron 5 polymorphism eliminates an MboI site. The restriction digestion was performed as described above and analysed on agarose gel electrophoresis. Those specific restriction analyses were utilized to determine the frequency of the variants.

\section{$P C R$-allele specific $L C R$}

To determine the frequency of exon 3 variant $A \mathbf{C T}^{110} \times \mathrm{ATT}$, substituting Thr ${ }^{110}$ to Ile, PCR-allele specific LCR was developed [37]. The following oligonucleotides were synthesized and used (Fig. 1,5' to 3'): TGCATCATTCTTT GGTGGGTGGC ( \# 439, common, sense-strand), TCATTCCACCAACTGCAAAGCTGG ( \# 438, common, antisense-strand), GTTCAGCTTTGCAGTTGGTGGAATGAC (\#435, Thr-specific, sensestrand), GTTCCACCCACCAAAGAATGATGCAG (\# 436, Thr-specific, antisense strand), CAGCTTTGCAGTTGGTGGAATGAT (\# 437, Ile-specific, sense-strand), CCACCCACCAAAGAATGATGCAA (\#440, Ile-specific, antisensestrand). As a target DNA for LCR assay, exon 3 of GLUT 2 gene was PCR amplified from genomic DNA with the condition used for PCR-SSCP analysis. One microlitre of the $10 \mu \mathrm{IPCR}$ product was used for LCR reaction. LCR was carried out in $10 \mu \mathrm{l}$ containing $1 \times$ ligation buffer $(20 \mathrm{mmol} / 1$ Tris- $\mathrm{Hcl} \mathrm{pH} 7.6,25 \mathrm{mmol} / 1 \mathrm{po}-$ tassium acetate, $10 \mathrm{mmol} / 1$ magnesium acetate, $10 \mathrm{mmol} / 1 \mathrm{di}$ thiothreitol, $1 \mathrm{mmol} / 1 \mathrm{NAD}, 0.1 \%$ Triton X-100), $1.5 \mathrm{U}$ Taq ligase (New England Biolabs, Beverly, Mass., USA), target DNA and $0.5 \mu \mathrm{mol} / 1$ each of the six primers with common sense-strand oligonucleotide (\#439) ${ }^{32} \mathrm{P}$-end labelled. Samples were processed through 35 cycles of a two-step chain reaction: $95^{\circ} \mathrm{C}$ for $1 \mathrm{~min}$ and $62^{\circ} \mathrm{C}$ for $1 \mathrm{~min}$ following a 4-min initial denaturation at $95^{\circ} \mathrm{C}$. After the thermal cycling, $6 \mu \mathrm{l}$ of stop solution (see above) was added and samples were analysed on a standard sequencing gel for $45 \mathrm{~min}$ to $1 \mathrm{~h}$. Gels were dried and subjected to autoradiography at $-80^{\circ} \mathrm{C}$ for 3 to $5 \mathrm{~h}$.

\section{Statistical analysis}

Biostatistical analysis was performed as previously described [32]. Briefly, differences between groups with quantitative variables were evaluated by unpaired (two-tailed) Student's $t$-tests and differences in proportions were evaluated by chi-square test. The association of variant alleles with NIDDM were analysed by $2 \times 2$ contingency tables. A chi-square test of independence was performed with Yates' correction applied on Fisher's exact test where appropriate. 
Table 2. GLUT 2 gene PCR primers and reaction conditions

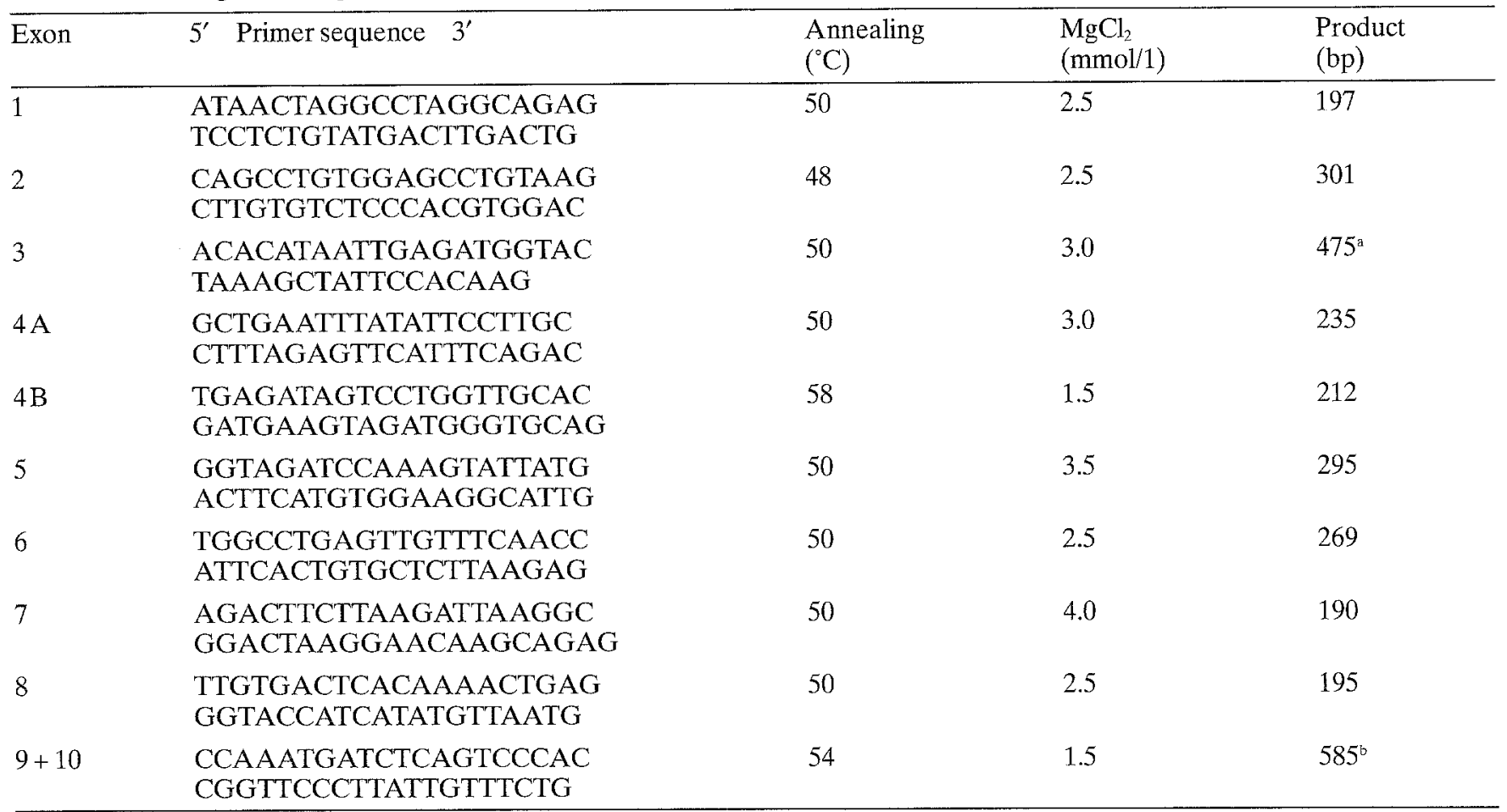

a 209 bp +266 bp after PvuII digestion; ${ }^{b} 240$ bp +345 bp after RsaI digestion

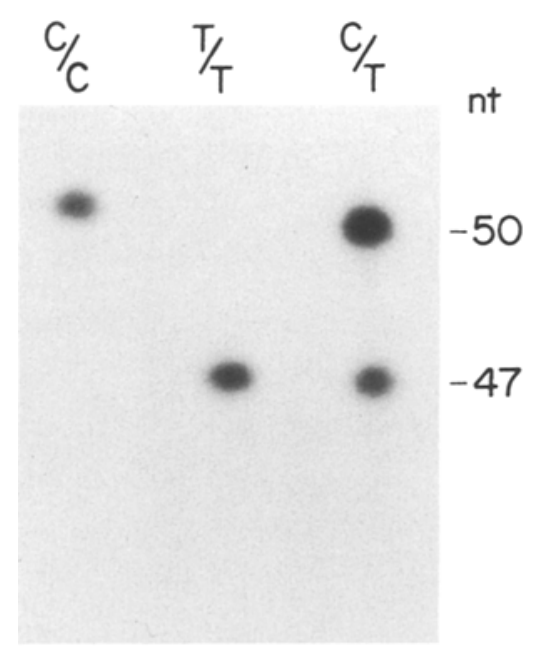

Fig. 2. Autoradiogram of PCR-LCR assay for ACT $\rightarrow$ ATT $\left(\mathrm{Thr}^{110} \rightarrow \mathrm{Ile}^{110}\right.$ ) change in exon 3 . The patterns corresponding to $\mathrm{C}$ homozygote $(\mathrm{C} / \mathrm{C})$, T homozygote $(\mathrm{T} / \mathrm{T})$ and $\mathrm{C} / \mathrm{T}$ heterozygote $(\mathrm{C} / \mathrm{T})$ are shown. The size of products in nucleotides (nt) are given on the right

\section{Results}

The entire coding region of the GLUT 2 gene was examined for single base changes in 48 NIDDM patients, directly from genomic DNA by PCR-SSCP analysis. A total of 12 SSCP variants were observed. The sequence changes responsible for the conformational polymorphisms were determined by direct sequencing of the PCR products and compared with the reported human GLUT 2 sequence [38]. Allelic frequencies for each variant were determined and are summarized in Table 3.

In the human GLUT 2 gene two amino acid substitutions were identified, one in exon 3 , and the other in exon $4 \mathrm{~B}$. The codon change in exon $3, \mathrm{ACT}^{110} \times$ ATT ${ }^{110}$, substituted Thr $^{110}$ to Ile ${ }^{110}$ in the second membrane spanning domain. To evaluate whether this amino acid substitution was associated with the diabetic phenotype, the frequency was determined in both diabetic patients and control subjects by a PCRLCR assay. For LCR assay, we designed the allele specific diagnostic oligonucleotides in a different length for each allele (Fig. 1), and LCR was performed under the presence of two diagnostic oligonucleotides specific for both alleles to determine the genotype by a single reaction. After the LCR, the products were separated by electrophoresis and two alleles were distinguished by the size of the products. The specificity of the assay was tested on the individuals whose genotypes were confirmed by sequencing. As shown in Figure 2, the specificity of the assay was high and there was virtually no background.

When typed, the $\mathrm{Thr}^{110}$ to Ile ${ }^{110}$ substitution was found to be common. In 48 NIDDM patients, Thr/Thr (homozygote) was observed in 18 individuals (37.5\%), Thr/Ile (heterozygote) in 22 individuals $(45.8 \%$ ), and Ile/Ile (homozygote) 8 individuals $(16.7 \%)$. The frequency in the 52 control subjects was: Thr/Thr 15 individuals $(28.8 \%)$, Thr/Ile 25 individuals $(48.1 \%)$ and Ile/Ile 12 individuals (23.1\%). The distribution of the 
Table 3. GLUT 2 variants (exon)

\begin{tabular}{|c|c|c|c|c|c|c|c|}
\hline \multirow[t]{2}{*}{ Location } & \multirow[t]{2}{*}{ Common } & \multirow[t]{2}{*}{ Variant } & \multirow[t]{2}{*}{ Allele } & \multicolumn{2}{|c|}{ NIDDM $^{\mathrm{a}}$} & \multicolumn{2}{|c|}{ Control $^{b}$} \\
\hline & & & & $n$ & {$[\%]$} & $n$ & {$[\%]$} \\
\hline Exon 3 & $\operatorname{ACT}\left(\operatorname{Thr}^{110}\right)$ & ATT(Ile) & $\begin{array}{l}\mathrm{C} \\
\mathrm{T}\end{array}$ & $\begin{array}{l}58 \\
38\end{array}$ & $\begin{array}{l}60.4 \\
39.6\end{array}$ & $\begin{array}{l}55 \\
49\end{array}$ & $\begin{array}{l}52.9 \\
47.1\end{array}$ \\
\hline \multirow[t]{2}{*}{ Exon $4 \mathrm{~B}$} & $\mathbf{G T C}\left(\mathrm{Val}^{197}\right)$ & ATC(Ile) & $\begin{array}{l}\mathrm{G} \\
\mathrm{A}\end{array}$ & $\begin{array}{r}95 \\
1\end{array}$ & $\begin{array}{r}99.0 \\
1.0\end{array}$ & $\begin{array}{r}104 \\
0\end{array}$ & $\begin{array}{r}100.0 \\
0.0\end{array}$ \\
\hline & $\operatorname{ACG}\left(\operatorname{Thr}^{198}\right)$ & $\operatorname{ACA}(T h r)$ & $\begin{array}{l}\mathrm{G} \\
\mathrm{A}\end{array}$ & $\begin{array}{l}67 \\
29\end{array}$ & $\begin{array}{l}69.8 \\
30.2\end{array}$ & $\begin{array}{l}71 \\
33\end{array}$ & $\begin{array}{l}68.3 \\
31.7\end{array}$ \\
\hline Exon 5 & CTG $\left(\operatorname{Leu}^{221}\right)$ & TTG(Leu) & $\begin{array}{l}\mathrm{C} \\
\mathrm{T}\end{array}$ & $\begin{array}{r}95 \\
1\end{array}$ & $\begin{array}{r}99.0 \\
1.0\end{array}$ & $\begin{array}{l}\text { ND } \\
\text { ND }\end{array}$ & \\
\hline Exon 8 & GTG $\left(\mathrm{Val}^{388}\right)$ & GTA(Val) & $\begin{array}{l}\mathrm{G} \\
\mathrm{A}\end{array}$ & $\begin{array}{r}95 \\
1\end{array}$ & $\begin{array}{r}99.0 \\
1.0\end{array}$ & $\begin{array}{l}\mathrm{ND} \\
\mathrm{ND}\end{array}$ & \\
\hline Exon 10 & $\operatorname{TTC}^{c}\left(\mathrm{Phe}^{479}\right)$ & TTT(Phe) & $\begin{array}{l}\mathrm{C} \\
\mathrm{T}\end{array}$ & $\begin{array}{l}43 \\
53\end{array}$ & $\begin{array}{l}44.8 \\
55.2\end{array}$ & $\begin{array}{l}\text { ND } \\
\text { ND }\end{array}$ & \\
\hline
\end{tabular}

${ }^{\mathrm{a}} n=96$ (48 individuals); ${ }^{\mathrm{b}} n=104$ (52 individuals); ${ }^{\mathrm{c}}$ Reported sequence [36]

ND, Not determined
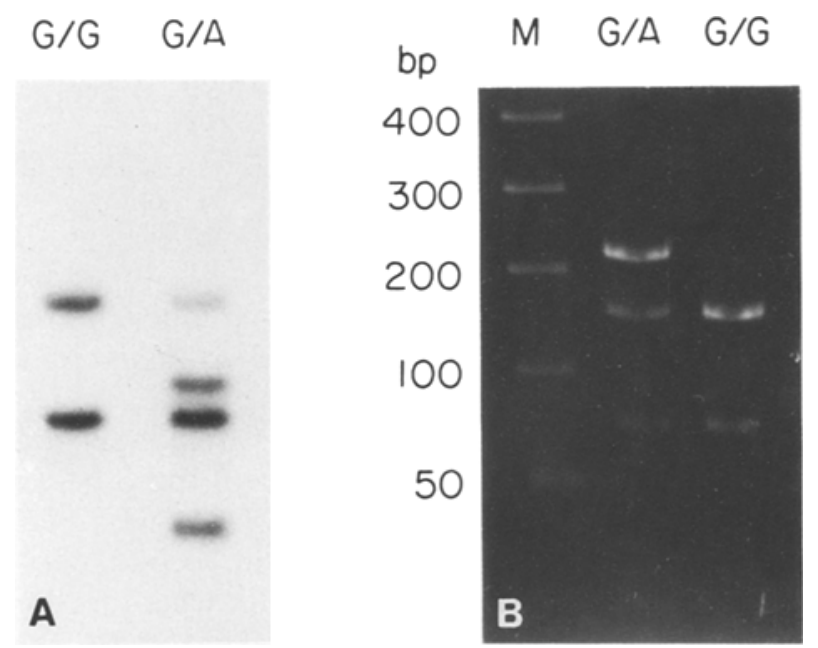

Fig. 3. A, B SSCP patterns observed in Exon 4B. The sequence changes responsible for the aberrant pattern $(\mathbf{G} \rightarrow \mathbf{A})$ was determined by sequencing (see text). G/G refers to the SSCP pattern corresponding to the homozygote of the common allele. G/A represents the pattern for the heterozygote for the common allele and the rare variant allele. B Restriction digestion of the exon 4 B PCR products from the individual shown in $\mathbf{A}$. The mutation removed an MaeIII restriction site (GTCAC $\rightarrow$ ATCAC). Digestion of the $\mathrm{PCR}$ product from the $\mathrm{G} / \mathrm{G}$ individual resulted in complete digestion of the $212 \mathrm{bp}$ product into two smaller fragments. The product from the G/A individual showed the uncleaved fragment in addition to the two smaller fragments

genotypic frequency was not different between the two groups $\left(\chi^{2}=1.11, p=0.58, d f=2\right)$. Allelic frequencies did not differ between the two groups, either (Table 2, $p=0.32$, Fisher's exact test).

The other missense mutation, $\left(\mathrm{Val}^{197}\right.$ to $\mathrm{Ile}^{197}$ ) in exon 4B (SSCP pattern shown in Fig. 3A), was found in 1 of 96 alleles in NIDDM patients, and in 0 of 104 alleles in normal control subjects. The presence of this mutation was further confirmed by restriction digestion of the exon $4 \mathrm{~B}$ PCR products (Fig. $3 \mathrm{~B}$ ). The muta- tion removed a Mae III restriction site $(\mathbf{G T C A C} \rightarrow \mathbf{A T}$ CAC).

Four additional silent mutations were identified in the coding region, two of which were common, ACG $\left(\mathrm{Thr}^{198}\right) \rightarrow \mathrm{ACA}\left(\mathrm{Thr}^{198}\right)$, allelic frequency of $30.2 \%$ and TTC $\left(\mathrm{Phe}^{479}\right) \rightarrow \mathrm{TTT}\left(\mathrm{Phe}^{479}\right)$, allelic frequency of $55.2 \%$. The other two were rare and observed in only one individual in heterozygous states with common alleles (Table 3 ). Six intron mutations were also found outside the consensus sequences of splice junction (Table 4). The intron 5 variant was common and observed in $38.5 \%$ of alleles in diabetic patients. These appeared to be functionally silent.

As we observed previously [32], glycerol gel is more sensitive to detect the base pair variation. The variations which result in the amino acid substitutions $\left(\mathrm{Thr}^{110}\right.$ and $\mathrm{Val}^{197}$ ) were detected on both gel conditions. All the variations were detected on the gel containing the glycerol, and all but one variant (substitution of $\mathrm{C}$ with $\mathrm{T}$ at -79 of intron) was detected on the non-glycerol gel.

\section{Discussion}

The entire coding sequence of the human GLUT 2 gene, encoded by 11 exons [39], including exon-intron boundaries and adjacent introns, was examined at the single nucleotide level by PCR-SSCP analysis. The patients chosen for study were African-American females who were diagnosed with gestational diabetes at perinatal examination, and developed overt diabetes after delivery. Pregnancy is a physiological state of insulin resistance [40]. It has been suggested that because all pregnant women are insulin resistant, those who have beta-cell dysfunction are more likely to develop diabetes during the gestational period [41]. Thus, the 
Table 4. GLUT 2 variants (intron)

\begin{tabular}{lllrr}
\hline Location $^{\mathrm{b}}$ & & & Allele & \multicolumn{1}{c}{ NIDDM $^{\mathrm{a}}$} \\
& & & $n$ & \multicolumn{1}{c}{$[\%]$} \\
\hline Intron 2 & +27 & $\mathrm{~T}$ & 95 & 99.0 \\
& & deletion & 1 & 1.0 \\
Intron 2 & -79 & $\mathrm{~T}$ & 95 & 99.0 \\
& & $\mathrm{C}$ & 1 & 1.0 \\
Intron 4A & +10 & $\mathrm{~A}$ & 95 & 99.0 \\
& & $\mathrm{~T}$ & 1 & 1.0 \\
Intron 5 & +19 & $\mathrm{~T}$ & 95 & 95.8 \\
& & $\mathrm{C}$ & 2 & 4.2 \\
Intron 5 & -15 & $\mathrm{C}$ & 59 & 61.5 \\
& & $\mathrm{~T}$ & 37 & 38.5 \\
Intron 7 & -9 & $\mathrm{~T}$ & 46 & 95.8 \\
& & $\mathrm{C}$ & 2 & 4.2 \\
\hline
\end{tabular}

${ }^{\mathrm{a}} n=96$ (48 individuals)

${ }^{b}$ Positions of variant nucleotides were shown either by the distance (nucleotides) from the upstream exon-intron boundary (positive number) or from the downstream exon-intron boundary (negative number)

GLUT 2 gene could be considered a prime candidate for genetic susceptibility of this type of diabetes. Relatively young onset of diabetes (mean age of diagnosis 32.7 years) and high positive family history of diabetes in this study population (90\%) also suggested a high prevalence of genetic predisposing factors in this population.

Two amino acid substitutions were found in the NIDDM patients. The missense mutation $\left(\mathrm{Val}^{197}\right.$ to $\mathrm{Ile}^{197}$ ) in exon $4 \mathrm{~B}$ was found in 1 allele of 48 diabetic patients ( 96 alleles), and was not observed in 52 normal control subjects (104 alleles). This residue exists in the fifth membrane spanning domain and Val at this position is conserved in mouse, rat GLUT 2 [42] and human GLUT 1 to GLUT 4 [42]. The functional significance of this mutation has yet to be determined by the kinetic study of the variant GLUT 2 expressed in Xenopus oocytes [43].

The Thr ${ }^{110}$ to Ile ${ }^{110}$ substitution in exon 3 was common. Neither the allelic nor genotypic frequencies differed between NIDDM patients and control subjects, showing no association between this amino acid substitution and the disease status, although sample size is rather small, and a minor contribution to the risk of disease susceptibility could not be excluded. This mutation was also observed in Pima Indians [44]. When compared with previously reported amino acid sequences of human glucose transporters, only GLUT 2 had Thr in this position, while other low $\mathrm{K}_{\mathrm{m}}$ transporters had Ile in the corresponding position [41]. Although in rat and mouse GLUT 2 [17], non-polar hydrophobic amino acid Val was found in the corresponding position, it would be still an interesting speculation that this nonconservative amino acid substitution in the second membrane spanning domain may alter the function by perhaps changing the affinity to glucose. This hypo- thesis can also be tested directly by the expression experiment [42].

No difference in either the allelic or genotypic frequency of these two amino acid substitutions was found between the diabetic and control groups, however the possibility of a minor contribution has not been excluded by the present study. The sample size examined was small relative to what may be needed to detect minor susceptible factors in polygenic diseases. A similar PCR-SSCP analysis of the angiotensinogen gene in a population of hypertensive patients required a study of 499 patients and 238 controls to demonstrate a highly significant role of variants of this gene in susceptibility to hypertension [45].

Although SSCP is a sensitive assay to detect a single base change, it is not a specific assay for a given nucleotide change and occasionally different base changes show indistinguishable patterns [46]. Therefore, to determine the frequency of the common amino acid substitution in exon 3, we utilized the allele specific LCR assay. Several allele specific assays have been developed including restriction enzyme digestion, allele specific oligonucleotide hybridization and allele specific PCR [47]. However, restriction analysis is only possible if the base change creates or eliminates a certain restriction site. Allele specific oligonucleotide hybridization and allele specific PCR require precise assay conditioning to verify the specificity.

An LCR relies on the character of thermostable ligase that links two adjacent oligonucleotides when these nucleotides hybridize to a complementary target and accurately base-pair at the junction [36]. In order to determine the genotype by a single reaction, here we designed the allele specific diagnostic oligonucleotides in a different length for each allele, and LCR was performed under the presence of two diagnostic oligonucleotides specific for both alleles. Under this condition, amplification was less efficient because for each allele, the presence of the mismatched oligonucleotide and its annealing to the target interferes with the LCR amplification of the allele. This was overcome by using PCR amplified target DNA rather than genomic DNA. After the LCR, two alleles were distinguished by size on electrophoresis. This simple and highly specific method would be useful to determine the frequency of single base change polymorphisms identified by SSCP, especially when those changes do not alter the restriction enzyme recognition sites.

In conclusion, we identified two variant GLUT 2 glucose transporters in a subset of patients with NIDDM. The rare variant in exon 4B may contribute to the diabetic susceptibility and awaits further investigation. However, structural abnormalities of the GLUT 2 transporter associated with NIDDM appeared to be rare. Although the sensitivity of PCRSSCP is not $100 \%$ [34] and regulatory regions of this gene were not examined in the current study, our analysis, combined with previous population association 
studies and linkage analyses, suggests that mutations in the GLUT 2 gene are not major determinants of diabetic susceptibility.

Acknowledgements. We are grateful to Dr. G. I. Bell (University of Chicago) for providing us with SSCP primer sequences of the GLUT 2 gene prior to publication. We also thank Ms. J. Wokur$\mathrm{ka}$ for help with manuscript preparation. This work was supported by grants from the NIH (DK16746, MAP; DK07120, KCC; DK20579, Diabetes Research and Training Center, Washington University School of Medicine; DK 32767, RTA).

\section{References}

1. DeFronzo RA (1988) Triumvirate: Beta-cell, muscle, liver: A collusion responsible for NIDDM. Diabetes 37: 667-687

2. Barnett AT, Eff C, Leslie RDG, Pyke DA (1981) Diabetes in identical twins. A study of 200 pairs. Diabetologia 20: 87-93

3. Knowler WC, Pettitt DJ, Saad MF, Bennett PH (1990) Diabetes mellitus in the Pima Indians: incidence, risk factors and pathogenesis. Diabetes Metab Rev 6: 1-27

4. Kawate R, Yamakido M, Nishimoto Y, Bennett PH, Hamman RF, Knowler WC (1979) Diabetes mellitus and its vascular complications in Japanese migrants on the island of Hawaii. Diabetes Care 2: 161-170

5. Steiner DF, Tager HS, Chan SJ, Nanjo K, Sanke T, Rubenstein AH (1990) Lessons learned from molecular biology of insulin-gene mutations. Diabetes Care 13: 660-669

6. Olansky L, Welling C, Giddings S et al. (1992) A variant insulin promoter in non-insulin-dependent diabetes mellitus. J Clin Invest 89: 1596-1602

7. Taylor S, Cama A, Accili D et al. (1991) Genetic basis of endocrine disease 1. Molecular genetics of insulin resistant diabetes mellitus. J Clin Endocrinol Metab 73: 1158-1163

8. Ballinger SW, Shoffner JM, Hedaya EV et al. (1992) Maternally transmitted diabetes and deafness associated with a $10.4 \mathrm{~kb}$ mitochondrial deletion. Nature Genetics 1 : $11-15$

9. Ouweland JMW, Lemkes HHPJ, Ruitenbeek W et al. (1992) Mutation in mitochondrial tRNA ${ }^{\text {Len(UUR) }}$ gene in a large pedigree with maternally transmitted type II diabetes mellitus and deafness. Nature Genetics 1:368-371

10. Reardon W, Ross RJM, Sweeney MG et al. (1992) Diabetes mellitus associated with a pathogenic point mutation in mitochondrial DNA. Lancet 340: 1376-1379

11. Froguel Ph, Vaxillaire M, Sun F et al. (1992) Close linkage of glucokinase locus on chromosome $7 \mathrm{p}$ to early-onset non-insulin-dependent diabetes mellitus. Nature 356: 162-164

12. Hattersley AT, Turner RC, Permutt MA et al. (1992) Linkage of type 2 diabetes to the glucokinase gene. Lancet 339 : $1307-1310$

13. Froguel Ph, Zouali H, Vionnet $\mathrm{N}$ et al. (1993) Familial hyperglycemia due to mutations in glucokinase: definition of a subtype of diabetes mellitus. N Engl J Med 328: 697-702

14. Permutt MA, Chiu KC, Tanizawa Y (1992) Glucokinase and NIDDM: a candidate gene that paid off. Diabetes 41: 13671372

15. Thorens B, Sarkar HK, Kaback HR, Lodish HF (1988) Cloning and functional expression in bacteria of a novel glucose transporter present in liver, intestine, kidney and $\beta$-pancreatic islet cells. Cell 55: 281-290

16. Permutt MA, Koranyi L, Keller K, Lacy PE, Sharp DW, Mueckler M (1989) Cloning and functional expression of a human pancreatic islet glucose transporter cDNA. Proc Natl Acad Sci USA 86: 8688-8692
17. Thorens B (1992) Molecular and cellular physiology of GLUT-2, a high- $\mathrm{K}_{\mathrm{m}}$ facilitated diffusion glucose transporter. Internatl Rev Cytol 137 A: 209-238

18. Newgard CB, Quaade C, Hughes SD, Milburn JL (1990) Glucokinase and glucose transporter expression in liver and islets: implications for control of glucose homeostasis. Biochem Soc Trans 18: 851-853

19. Unger RH (1991) Diabetic hyperglycemia: link to impaired glucose transport in pancreatic $\beta$ cell. Science 251: 1200-1205

20. Matschinsky FM (1990) Glucokinase as glucose sensor and metabolic signal generator in pancreatic beta-cell and hepatocytes. Diabetes 39: 647-652

21. Tal M, Liang Y, Najafji H, Lodish H, Matschinsky FM (1992) Expression and function of GLUT-1 and GLUT-2 glucose transporter isoforms in cells of cultured rat pancreatic islets. J Biol Chem 267: 17241-17247

22. Matsutani A, Koranyi L, Cox N, Permutt MA (1990) Polymorphisms of GLUT2 and GLUT4 genes. Use in evaluation of genetic susceptibility to NIDDM in Blacks. Diabetes 39: 1534-1542

23. Patel P, Bell GI, Cook JTE, Turner RC, Wainscoat JS (1991) Multiple restriction fragment length polymorphisms at the GLUT 2 locus: GLUT 2 haplotypes for genetic analysis of type 2 (non-insulin-dependent) diabetes mellitus. Diabetologia 34: 817-821.

24. Baroni MG, Alcolado JC, Pozzilli P, Cavallo MG, Li S-R, Galton DJ (1992) Polymorphisms at the GLUT2 $(\beta$ cell/liver) glucose transporter gene and non-insulin-dependent diabetes mellitus (NIDDM): analysis in affected pedigree members. Clin Genet 41:229-234

25. Patel P, Lo YMD, Hattersley A et al. (1992) Linkage analysis of maturity-onset diabetes of the young with microsatellite polymorphisms. No linkage to ADA to or GLUT2 genes in two families. Diabetes 41: 962-967

26. Elbein SC, Hoffman MD, Matsutani A, Permutt MA (1992) Linkage analysis of GLUT1 (HepG2) and GLUT2 (liver/islet) genesinfamilial NIDDM.Diabetes41:1660-1667

27. Alcolado JC, Baroni MG, Li SR (1991) Association between a restriction fragment length polymorphism at the liver/islet cell (GLUT2) glucose transporter and familial type 2 (noninsulin-dependent) diabetes mellitus. Diabetologia 34: 734736

28. Cox NJ, Bell GI (1989) Disease associations: chance, artifact, or susceptibility genes? Diabetes 38: 947-950

29. O'Rahilly S, Wainscoat JS, Turner RC (1988) Type 2(non-insulin-dependent) diabetes mellitus: new genetics for old nightmares. Diabetologia 31: 407-414

30. Lander ES, Botstein D (1986) Strategies for studying heterogeneous genetic traits in human by using a linkage map of restriction fragment length polymorphisms. Proc Natl Acad Sci USA 83: 7353-7357

31. Orita M, Suzuki Y, Sekiya T, Hayashi K (1989) Rapid and sensitive detection of point mutation and DNA polymorphisms using the polymerase chain reaction. Genomics 5: 874879

32. Chiu KC, Go RCP, Aoki M, Riggs AC, Tanizawa Y, Acton RT et al. (1994) Glucokinase gene in gestational diabetes mellitus: population association study and molecular scanning. Diabetologia 37: 104-110

33. Acton RT, Vanichanan CJ, Perkins L et al. (1990) Immunogenetic predictors of gestational diabetes in American Blacks. In: Andreani D, Bompiani GD, Di Mario U, Faulk WP, Galluzzo A (eds), Immunobiology of normal and diabetic pregnancy. John Wiley \& Sons, Ltd., New York, pp 207-220

34. Kunkel LM, Smith RD, Soyer SH et al. (1977) Analysis of human $\mathrm{Y}$ chromosome specific reiterated DNA in 
chromosome variants. Proc Natl Acad Sci USA 74: 12451249

35. Chiu KC, Tanizawa Y, Permutt MA (1993) Glucokinase gene variants in the common form of NIDDM. Diabetes 42: 579 582

36. Matsutani A, Hing A, Steinbrueck T et al. (1992) Mapping the human liver/islet glucose transporter (GLUT2) gene within a genetic linkage map of chromosome $3 \mathrm{q}$ using a (CA)n dinucleotide repeat polymorphism and characterization of the polymorphism in three racial groups. Genomics 13: 495-501

37. Barany F (1991) Genetic disease detection and DNA amplification using cloned thermostable ligase. Proc Natl Acad Sci USA 88: 189-193

38. Fukumoto H, Seino S, Imura $\mathrm{H}$ et al. (1988) Sequence, tissue distribution, and chromosomal localization of mRNA encoding a human glucose transporter-like protein. Proc Natl Acad Sci USA 85: 5434-5438

39. Takeda J, Kayano T, Fukumoto H, Bell GI (1993) Organization of the human GLUT2 (pancreatic $\beta$-cell and hepatocyte) glucose transporter gene. Diabetes 42: 773-777

40. Cousins L (1991) Insulin sensitivity in pregnancy. Diabetes 40 [Suppl 2]: 39-43
41. Kühl C (1991) Insulin secretion and insulin resistance in pregnancy and GDM. Implications for diagnosis and management. Diabetes 40 [Suppl 2]: 18-24

42. Bell GI, Kayano T, Buse JB et al. (1990) Molecular biology of mammalian glucose transporters. Diabetes Care 13: 198-208

43. Keller K, Strube M, Mueckler M (1990) Functional expression of the human HepG2 and rat adipocyte glucose transporters in Xenopus oocytes. Comparison of kinetic parameters. J Biol Chem 264: 18884-18889

44. Janssen R, Bogardus C, Takeda J, Thompson DB (1993) A threonine for isoleucine substitution in a membrane spanning domain of the human islet/liver glucose transporter gene. Diabetes 42 [Suppl 1]: 110A (Abstract)

45. Jeunemaitre X, Soubrier F, Koteletsev YV et al. (1992) Molecular basis of human hypertension: role of angiotensigen. Cell 71: 169-180

46. Elbein SC, Sorensen LK, Schumacher MC (1993) Methionine for valine substitution in exon 17 of the insulin receptor gene in a pedigree with familial NIDDM. Diabetes 42 : 429-434

47. Cotton RGH (1989) Detection of single base change in nucleic acid. Biochem J 263: 1-10 